\section{JAES \\ AÇEH}

Journal of Anatolian

Environmental\&Animal Sciences

Vol: 1, No: 3, 2016 (100-101)

Anadolu Çevre ve Hayvancılık Bilimleri Dergisi

Vol: 1, No:3, 2016 (100-101)

Editorial Letter / Editöre Mektup

\title{
Expert Ideas for Sustainable Development Goals in the Mid-Latitude Region (MLR)
}

\author{
Nüket SIVRI* \\ *Istanbul University, Engineering Faculty, Environmental Engineering Department, 34320, Istanbul, Turkey
}

\section{Introduction and Background}

Nations came together last September in New York to adopt the 2030 Agenda for Sustainable Development and its 17 Sustainable Development Goals (SDGs) (Figure 1). 169 targets were proposed and it was highlighted to promote efficiencies and synergies. This is a truly historic agreement, providing a shared vision of the future with an integrated approach to development, enabling governments, businesses, civil society organizations, and individuals to effectively and collectively navigate their way toward a sustainable future in a manner never experienced before at a global level (UNOSD MLR EGM- 9).
About these Sustainable Development Goals, we summarized briefly:

Goal 1. End poverty in all its forms everywhere

Goal 2. End hunger, achieve food security and improved nutrition and promote sustainable agriculture

Goal 3. Ensure healthy lives and promote well-being for all at all ages

Goal 4. Ensure inclusive and equitable quality education and promote lifelong learning opportunities for all

Goal 5. Achieve gender equality and empower all women and girls
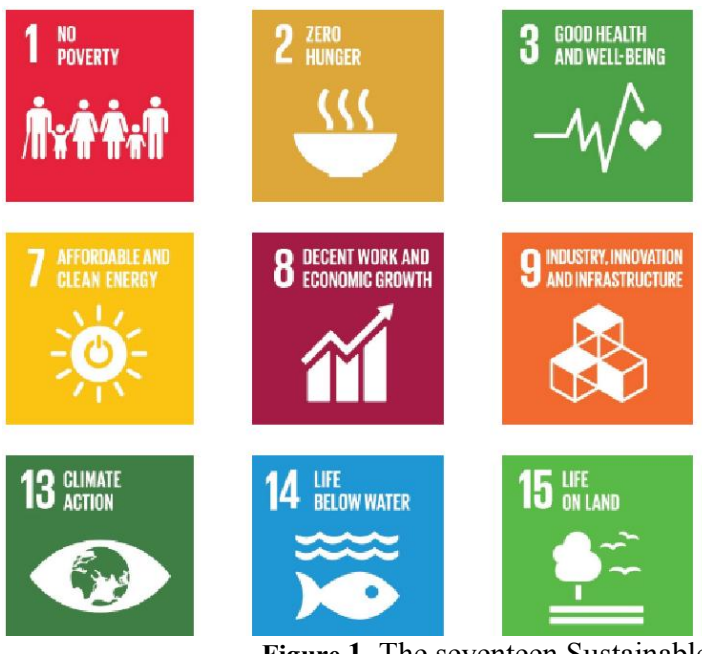
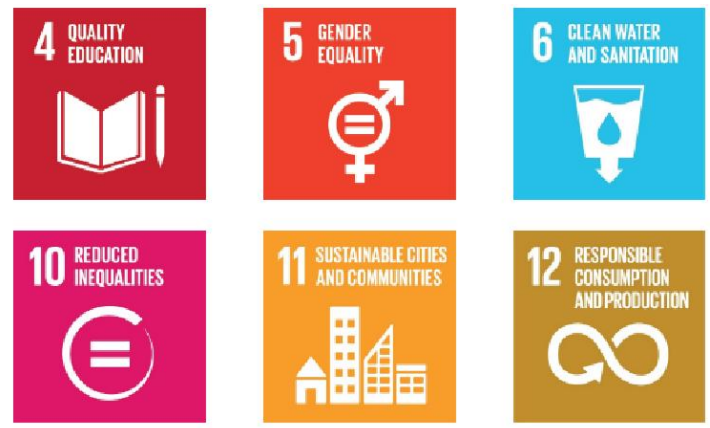

Figure 1. The seventeen Sustainable Development Goals (SDGs) (URL 1)
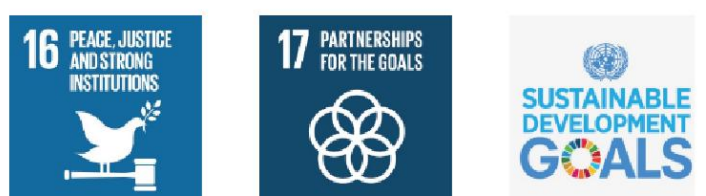

Goal 6. Ensure availability and sustainable management of water and sanitation for all

Goal 7. Ensure access to affordable, reliable, sustainable and modern energy for all

Goal 8. Promote sustained, inclusive and sustainable economic growth, full and productive employment and decent work for all

Goal 9. Build resilient infrastructure, promote inclusive and sustainable industrialization and foster innovation
Goal 10. Reduce inequality within and among countries Goal 11. Make cities and human settlements inclusive, safe, resilient and sustainable

Goal 12. Ensure sustainable consumption and production patterns

Goal 13. Take urgent action to combat climate change and its impacts (Acknowledging that the United Nations Framework Convention on Climate Change is the primary international, intergovernmental forum for negotiating the global response to climate change) 
Goal 14. Conserve and sustainably use the oceans, seas and marine resources for sustainable development

Goal 15. Protect, restore and promote sustainable use of terrestrial ecosystems, sustainably manage forests, combat desertification, and halt and reverse land degradation and halt biodiversity loss

Goal 16. Promote peaceful and inclusive societies for sustainable development, provide access to justice for all and build effective, accountable and inclusive institutions at all levels

Goal 17. Strengthen the means of implementation and revitalize the Global Partnership for Sustainable Development (URL 2).

After these decisions, it was agreed to organize "Expert Group Meeting on Achieving the Sustainable Development Goals with Water-Food-Ecosystem Resilience in the Mid-Latitude Region (MLR)"by the United Nations Office for Sustainable Development (UNOSD) of UNDESA in Seoul, Korea. The United Nations Office for Sustainable Development (UNOSD) hosted the Expert Group Meeting (EGM) on water-food-ecosystem resilience in collaboration with the Sustainable Development Solutions Network (SDSN) Korea, the Korean Ministry of Environment and Korea University in 28-29 November 2016. In this meeting, it was aimed to build resilience inthe inextricably linked nexus ofwater, food and ecosystems. Key objectives of the meeting were to improve understanding of the interdependence of water-foodecosystem from scientific perspectivesand to share knowledgeand experiencein the mid-latitude region on the challenges and opportunities in achieving the Sustainable Development Goals related to water, food andtheterrestrial ecosystem.

\section{Objectives and Outputs of Expert Group Meeting}

The objectives of this expert meeting, with major focus on developing countries in the mid-latitude regions, are: 1) better understanding of the interdependence of water-food-ecosystem from scientific perspectives; 2) knowledge sharing in the midlatitude region on the challenges and opportunities in achieving the Sustainable Development Goals related to water, food and terrestrial ecosystem; and 3) professional networking among participating organizations, countries and regions to promote further study and active debate on cross-sectoral integration and the water-food-ecosystem resilience. The meeting has produced a meeting report summarizing the presentations and key discussion points for wider knowledge basis on water-food-ecosystem resilience in the mid-latitude regions.

This meeting has included 4 main sessions and had designed (URL 3):

1. To provide the overview of the water-food-ecosystem resilience and its importance to achieve the Sustainable Development Goals. It provided a brief overview of Midlatitude region focusing on common challenges.

2. To share current scientific and technological knowledge on water-food-ecosystem resilience. This session focused on the synergies and trade-offs in achieving water-foodecosystem resilience and the research agenda to address the complexity of the emerging nexus issue.

3. To have presentations and discussion on the current status and challenges of applying integrated approaches to achieve water-food-ecosystem resilience in the country level. Participants from developing and developed countries shared specific examples of their success/failure.

4. To have discussion on current transboundary cooperation efforts and opportunities in the mid-latitude region. The session also had discussion on implementation of waterfood-ecosystem resilience at different scales and how these scales are linked with one another. The session had been facilitated through group and plenary discussion to explore practical options for regional cooperation and international cooperation.

\section{Main Results after the Expert Group Meeting (EGM)}

MLR is unique for many reasons: a large region extending over the Earth spanning all longitudes, climate change adaptation/mitigation, and sustainable development in terms food/water/energy and all the ecosystem totally. Furthermore, resilience is especially challenged by low precipitation, increase temperature, low crop land fertility, food security (especially GDO).

After this meeting, the expert meeting groupagreed on several topics and approaches. They decided to identify high priority target projects. An extensive meeting report will be announced in UNOSD's official website (URL 4).

\section{References}

URL., 1. UN, http://www.un.org/sustainabledevelopment/ sustainable-development-goals/(Accessed in 02.12.2016).

URL., 2. UN, http://www.un.org/ga/search/view doc.asp?symbol $=\mathrm{A} / \mathrm{RES} / 70 / 1$ \&Lang=E. (Accessed in 02.12.2016).

URL., 3. UNOSD, http://www.unosd.org/content/documents /2087EGM Agenda \%20(v.7)_161124\%20(1).pdf. (Accessed in 02.12.2016).

URL., 4. UNOSD, http://www.unosd.org/index.php?page=view\& type $=13 \&$ nr=54\&menu $=177$ (Accessed in 02.12.2016).

Geliş tarihi: 05.12 .2016

Kabul tarihi: 09.12.2016

\author{
*Başlıca Yazar Yazışma adresi: \\ Prof. Dr. Nüket SIVRI \\ İstanbul University, Engineering Faculty, Environmental \\ Engineering Department, 34320, Istanbul, Turkey. \\ E-mail: nuket@istanbul.edu.tr
}

